\title{
Effect of Storage Materials on Viability and Proximate Composition of Garcinia kola Heckel
}

\section{*1 OLAYINKA, BU; ${ }^{1}$ OLAHAN, GS; ${ }^{1}$ OBADIRE, TO; ${ }^{2}$ RAIYEMO, DA; ${ }^{1}$ MOHAMMED, RT}

\author{
${ }^{1}$ Department of Plant Biology, University of Ilorin, Ilorin, Nigeria \\ ${ }^{2}$ Department of Agricultural Biotechnology and Bioresources Development, National Biotechnology Development Agency, South West BIODEC \\ Zonal Centre Owode Yewa South, Ogun state, Nigeria \\ *Correspondence E-mail: olayinka.bu@unilorin.edu.ng
}

\begin{abstract}
The viability and proximate composition of Garcinia kola Heckel as affected by different storage materials were studied using standard methods. Viability of the G. kola seeds stored in polyethylene bag (PB) was highest (100\%) followed by that of the seeds stored in fresh plantain leaf (FPL) $(86.67 \pm 13.33 \%)$; cement bag paper (CBP) (73.33 $\pm 17.64 \%$ ); dry plantain leaf (DPL) $(60.00 \%)$ and the control which was exposed to the ambient temperature in the laboratory $(33.33 \pm 6.67 \%)$. Seeds stored in sawdust were not viable at the end of the experiment. Pre-storage proximate analyses showed that the seeds have high level of carbohydrates $(52.00 \%)$, high moisture content $(38.07 \%)$, and little amount of crude fat $(4.18 \%)$, crude fibre $(2.88 \%)$ and crude protein $(2.09 \%)$ as well as negligible amount of ash content $(0.78 \%)$. Results of post - storage proximate analyses showed that control seeds have higher carbohydrate, crude fibre, ash and crude protein contents with mean values of $80.71 \pm 0.05 \%, 3.74 \pm 0.01 \%, 1.11 \pm 0.13 \%$ and $3.16 \pm 0.01 \%$ respectively, compared to the results obtained from pre - storage proximate analysis. Moisture content of control seeds was lowest $(9.24 \pm 0.03 \%)$ compared to seeds stored in the other storage materials. Seeds stored in polythene bag showed the lowest carbohydrate and crude protein contents of $47.65 \pm 0.17 \%$ and $1.80 \pm 0.01 \%$ respectively. The same storage material contained highest amount of moisture $(44.21 \pm 0.76 \%)$. Seeds stored in cement bag, sawdust, fresh plantain leaf and dry plantain leaf have varying contents of carbohydrates, moisture, ash, crude fibre, crude fat and crude protein contents which were either higher or lower than those of the control and the polythene bag. The results showed that polythene bag favoured the longevity of the seeds as complete retention of viability occurred after 8 weeks in storage when compared to other storage materials. However, carbohydrate and protein in seeds were significantly reduced in this storage material. (C) JASEM http://dx.doi.org/10.4314/jasem.v20i3.36
\end{abstract}

Keywords: Garcinia kola, post-storage, pre-storage, proximate analyses, storage materials, viability.

Garcinia kola is an angiosperm which belongs to the Family Clusiaceae. In Nigeria, the tree grows wild in Southern rainforest ecological zone, most importantly in forest reserves and free areas of the rainforest (Aiyelaagbe et al., 1996). It is also planted or conserved on farms of oil-palm and cocoa-yam plantations (Adebisi, 2004). The plant requires annual rainfall of 2,000 to $2,500 \mathrm{~mm}$, temperatures of 21 $32^{\circ} \mathrm{C}$ and a minimum relative humidity of $76 \%$ (Ntamag, 1997). It fruits between July and October and harvesting is done in these period. This therefore makes it a highly seasonal produce. The fruit is reddishyellow, about $6 \mathrm{~cm}$ in diameter, and each fruit contains two to four brown seeds embedded in an orangecoloured pulp (Ladipo, 1995). G. kola is known by various names such as bitter kola, male kola, false kola (English language), Orogbo (Yoruba), Akuilu (Igbo) and Namijingoro (Hausa).

Apart from being a stimulant, G. kola nut has a bitter astringent and resinous taste when chewed. It is often used as an aphrodisiac (Adesuyi et al., 2012). It is highly valued for its perceived medicinal attributes and unlike Kola nut, the fact that consumption of large quantities does not cause indigestion makes it a highly desired product (Adebisi, 2004). The seed is used for curing cough, toothache, fever, diabetes and also as a stimulant. Bitter kola is rich in caffeine and theobromine. It is believed to clean the digestive system, without side effects such as abdominal problems, even when a lot of nuts are eaten (Onochie and Stanfield, 1960). Ofor et al. (2004) identified several ethno-botanical uses of $G$. kola seeds practiced by the indigenes of Imo State in South-Eastern Nigeria. These include its use as an antidote for snake bites, poison and overdose, snake repellents and vomiting.

Considering the various uses of $G$. kola seeds, efforts have been made to study the most appropriate storage material for increasing the shelf life of the seeds (Ofor et al., 2004). In all the materials used (polythene bag, cement bag, fresh and dry plantain leaf as well as sawdust) by market women in storing the seed, polythene bag was found to give the best result. On this premise, the present study was designed to further evaluate the effect(s) of these storage materials on viability and proximate composition of G. kola seeds.

\section{MATERIALS AND METHODS}

Collection of seeds: Fresh seeds of G. kola were collected from Ifaki Farm in Ijero-Ekiti, Ekiti State, a forest zone vegetation belt in South-Western part of Nigeria.

Experimental design and Treatments: Five storage materials namely Polyethylene Bags (PB), Cement Paper Bag (CPB), Dry Plantain Leaf (DPL), Fresh Plantain Leaf (FPL), and Sawdust (SD) which have been established as materials used by market women for storing seeds were used (Ofor et al., 2010). The seeds were stored in the various storage materials under study for eight (8) weeks. The set up was arranged following a Complete Randomized Design (CRD) with three replications. Ten seeds were wrapped up in each of the storage materials. The control treatment had 
their seeds exposed to laboratory room temperature (28 $-30^{\circ} \mathrm{C}$ ). Initial fresh weight of the seeds in each storage materials was recorded and thereafter, weekly weight of the seeds was determined using MP 1001 weighing balance for a period of eight weeks.

Viability test: Seed viability was determined using flotation method. This method involved soaking the seed one after the other into a $500 \mathrm{ml}$ beaker containing water and allowing the seeds to settle for 10 minutes. Seeds that sank were considered viable while those that floated were most likely not viable. This viability test was carried out after eight weeks of storage, and the \% viability of the seeds stored in each of the storage materials was determined following the formula below:

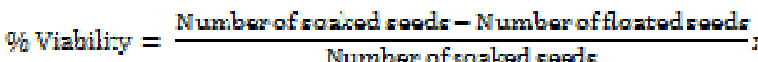

Proximate analyses of $G$. kola seeds: Proximate analysis was carried out on the ground seeds of G. kola before and after subjecting the seeds to the different storage conditions following the methods of Association of Official Analytical Chemists (AOAC, 2000). Moisture content was determined by heating 2.0 $\mathrm{g}$ of the ground sample to a constant weight in a crucible placed in an oven at $105^{\circ} \mathrm{C}$ for 5 hours. Ash was determined by incinerating $10.0 \mathrm{~g}$ of the ground sample placed in a muffle furnace at $550{ }^{\circ} \mathrm{C}$ for 5 hours. Crude fibre was obtained by digesting $2.0 \mathrm{~g}$ of the sample with $\mathrm{H}_{2} \mathrm{SO}_{4}$ and $\mathrm{NaOH}$. The resulting residue was incinerated in a muffle furnace at $550{ }^{\circ} \mathrm{C}$ for 5 hours. Crude protein (\% total nitrogen x 6.25) of $2.0 \mathrm{~g}$ of each sample was determined using the Kjeldahl method. Crude fat was determined by extracting $5.0 \mathrm{~g}$ of the ground sample in a Soxhlet extractor using petroleum ether (at $60^{\circ} \mathrm{C}$ boiling point). Total carbohydrate was determined by summing up the percentage moisture, ash, crude fibre, crude fat and protein contents and subtracting same from 100. Each parameter was determined in triplicate.

Data analysis: Data were analyzed using Statistical Package for Social Science (SPSS) software version 17. Means were separated using Duncan Multiple Range Test (DMRT) at 5\% level of probability.

\section{RESULTS AND DISCUSION}

The results of viability tests after 8 weeks of storage are presented in Table 1. It was observed that viability was significantly highest when stored in polyethylene bag with $100 \%$ viable seeds, followed in decreasing order by seeds stored in fresh plantain leaf $(86.67 \pm 13.33)$, cement bag paper $(73.33 \pm 17.64)$, dry plantain leaf (60.00) and control $(33.33 \pm 6.67)$. Seeds stored in sawdust were no longer viable after eight weeks of storage (Table 1).

Table 1: Seed viability of $G$. kola seeds as affected by the different storage materials after 8 weeks storage

\begin{tabular}{ll}
\hline Storage materials & Viability $(\%)$ \\
\hline Cement Bag Paper & $73.33 \pm 17.64^{\mathrm{ab}}$ \\
Polyethylene & $100 \pm 0.00^{\mathrm{a}}$ \\
\hline
\end{tabular}

\begin{tabular}{ll}
\hline Sawdust & $0.00 \pm 0.00^{\mathrm{d}}$ \\
Fresh plantain leaf & $86.67 \pm 13.33^{\mathrm{ab}}$ \\
Dry plantain leaf & $60.00 \pm 0.00^{\mathrm{bc}}$ \\
Control & $33.33 \pm 6.67^{\mathrm{c}}$ \\
\hline
\end{tabular}

Values followed by the same superscripts along the column are statistically the same at $\mathrm{p} \leq 0.05$; Values are means of 3 replicates \pm Standard Error of Means (SEM)

The results of seed weight as influenced by different storage materials are presented in Fig. 1. In all the storage materials there was general decrease in seed weight from first week till 8th week. At 8 weeks, seeds stored in polyethylene had the highest weight, followed in decreasing magnitude by those of seeds stored in fresh plantain leaf, saw dust, dry plantain leaf and cement (Fig.1). Lowest seed weight was recorded in the control.

Table 2 shows the results of proximate analyses of $G$. kola seeds before and after 8 weeks in the storage materials investigated. A closer look at the pre and post proximate composition showed that there was a general increase in carbohydrate and crude protein in the post proximate compared to pre-proximate compositions in all the storage materials except in those seeds stored in polyethylene. Conversely, crude fat was reduced after 8 weeks of storage in different storage materials. Moisture followed the same pattern as crude fat except in seed stored in polyethylene (Table 2). Results of other proximate parameters such as ash and fibre fluctuated as it decreased or increased in one form of storage material to the other.

Different storage materials significantly $(\mathrm{p} \leq 0.05)$ affected the post proximate composition of the seeds. Percentage moisture, ash, crude fibre, crude fat, crude protein and carbohydrate content of the G. kola seeds ranged from $9.24-44.21 \%, 2.91-3.79 \%, 2.04-$ $3.81 \%, 1.80-3.16 \%, 0.20-1.11 \%$ and $47.65-$ $80.71 \%$ respectively (Table 2 ).

Percentage moisture content of G. kola seeds stored in the cement bag and sawdust were statistically similar but significantly lower than those stored in the other storage materials. Significantly highest ash and crude fibre contents were recorded in the control seeds, followed in decreasing order by those of seeds stored in cement bag, sawdust, dry plantain leaf, polyethylene bag and fresh plantain leaf (Table 2). Higher crude fat contents were recorded in seeds stored in fresh plantain leaf, polyethylene, dry plantain leaf, cement bag and the control.

Results of protein and carbohydrate contents showed similar pattern in that significantly highest values of these parameters were recorded in seeds stored in control seeds, followed in decreasing order by those of seeds stored in sawdust, cement bag, dry plantain leaf, fresh plantain leaf and polyethylene bag. Carbohydrate content was found to be highest with mean values of $68.91 \%$, followed by moisture content $(21.78 \%$ ), crude fibre content (3.20\%), crude fat 
Table 2: Proximate analyses of $G$. kola after being stored for eight weeks using different storage materials

\begin{tabular}{|c|c|c|c|c|c|c|}
\hline & \multicolumn{6}{|c|}{ Pre - storage proximate composition (\%) } \\
\hline & Moisture & $\begin{array}{l}\text { Ash } \\
\text { Content }\end{array}$ & Crude fibre & Crude fat & Crude protein & Carbohydrate \\
\hline & 38.07 & 0.78 & 2.88 & 4.18 & 2.09 & 52.00 \\
\hline & \multicolumn{6}{|c|}{ Post - storage proximate composition (\%) } \\
\hline Storage materials & Moisture & $\begin{array}{c}\text { Ash } \\
\text { Content }\end{array}$ & Crude fibre & Crude fat & Crude protein & Carbohydrate \\
\hline Cement Bag & $10.00 \pm 0.21^{\mathrm{d}}$ & $0.93 \pm 0.52^{\mathrm{b}}$ & $3.52 \pm 0.18^{b}$ & $2.27 \pm 0.01^{\mathrm{e}}$ & $3.04 \pm 0.01^{\mathrm{c}}$ & $80.25 \pm 0.17^{\mathrm{a}}$ \\
\hline Polyethylene & $44.21 \pm 0.76^{\mathrm{a}}$ & $0.22 \pm 0.12^{\mathrm{e}}$ & $2.82 \pm 0.01^{\mathrm{e}}$ & $3.30 \pm 0.02^{\mathrm{b}}$ & $1.80 \pm 0.01^{\mathrm{f}}$ & $47.65 \pm 0.17^{\mathrm{d}}$ \\
\hline Sawdust & $9.60 \pm 0.34^{\mathrm{d}}$ & $0.84 \pm$ & $3.42 \pm 0.02^{\mathrm{c}}$ & $2.54 \pm 0.02^{\mathrm{d}}$ & $3.10 \pm 0.01^{\mathrm{b}}$ & $80.50 \pm 0.06^{\mathrm{a}}$ \\
\hline Fresh Plantain Leaf & $35.90 \pm 0.16^{\mathrm{b}}$ & $0.20 \pm 0.12^{\mathrm{e}}$ & $2.41 \pm 0.01^{\mathrm{f}}$ & $3.81 \pm 0.01^{\mathrm{a}}$ & $2.10 \pm 0.00^{\mathrm{e}}$ & $55.59 \pm 0.18^{c}$ \\
\hline Dry Plantain Leaf & $21.65 \pm 3.30^{\mathrm{c}}$ & $0.52 \pm 0.01^{\mathrm{d}}$ & $3.30 \pm 0.02^{\mathrm{d}}$ & $3.04 \pm 0.03^{\mathrm{c}}$ & $2.72 \pm 0.02^{\mathrm{d}}$ & $68.76 \pm 3.32^{b}$ \\
\hline Control & $9.24 \pm 0.03^{\mathrm{d}}$ & $1.11 \pm 0.13^{\mathrm{a}}$ & $3.74 \pm 0.01^{\mathrm{a}}$ & $2.04 \pm 0.03^{\mathrm{f}}$ & $3.16 \pm 0.01^{\mathrm{a}}$ & $80.71 \pm 0.05^{\mathrm{a}}$ \\
\hline
\end{tabular}

Values followed by the same superscript along the row are statistically the same at $\mathrm{p} \leq 0.05$; Values are mean of 3 replicates \pm SEM

Figure 1 shows the weekly weight of the seeds during the period of storage. There is a general decrease in the weight of the seeds from the first week of storage (WK 1) to the last week of storage (WK 8) regardless of the storage material.

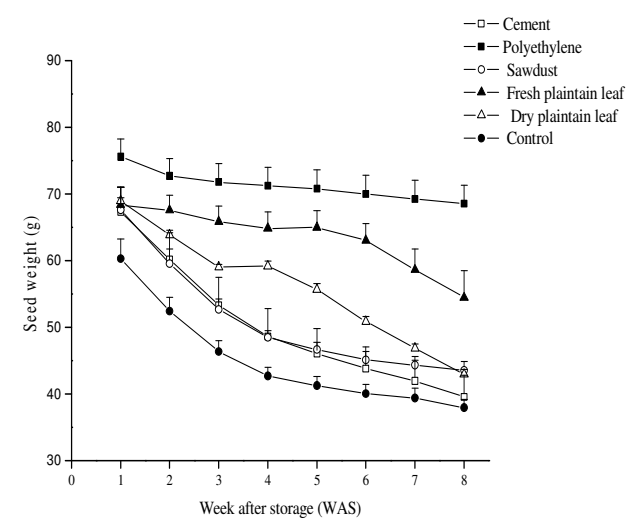

Fig 1: Weekly fresh weight of G. kola seeds in the different storage materials.

Viability of the G. kola seeds stored in polyethylene bag (PB), fresh plantain and saw dust was better after 8 weeks in storage than those of seeds stored in other materials investigated. The enhanced viability is attributed to the fact that seeds stored using these materials were able to retain moisture optimum enough to keep the embryo alive. Evidence in support of this assertion is observed in hundred per cent viability recorded in polyethylene that has the highest moisture content. Oboho and Ngalum (2014) had observed that storing seeds of Treculia africana in air-tight container retained the moisture enough to sustain the viability of the seeds for long time compared to those stores in jute bag and open basket. Similarly, Nwoboshi (1982) had observed that seeds which do not possess hard impervious seed coat like G. cola and Gliricida sepium lose their viability rapidly as they were subjected to temperature and humidity fluctuations. This goes further to say that highest percentage seeds viability recoded in polyethylene is due to ability of this material to protect G. kola seeds from temperature and humidity.

Proximate analyses of $G$. kola seeds showed significant difference at $\mathrm{p}<0.05$ after storage in the different storage materials as well as in the control. Carbohydrates were found to be highest, ranging from $47.65 \pm 0.17-80.71 \pm 0.05 \%$ regardless of the storage material. This is similar with the reports of Adesuyi et al. (2012), who stated that carbohydrates are the most abundant biological molecules in the seeds of G. kola. Carbohydrates play important roles in the body as sources of energy as well as structural materials (Voet et al., 2012). Moisture content which followed carbohydrates was found to be high in seeds stored in the polyethylene bag with a value of $44.21 \pm 0.76$. It should be noted that the high percentage moisture content in the seeds stored in the polythene bag tend to limit the amount of carbohydrate in the seeds stored in the storage material and vice versa. The implication of this trend is that the loss of moisture reduced seed weight with concomitant increase in carbohydrate content of the seeds. This explanation could account for the high carbohydrate content recorded in the seeds with low percentage moisture content. Moisture content of the seeds contributes to the seed weight and affects the carbohydrate content of the seeds. Water is a universal solvent, dissolving other substances; it carries nutrients and various materials round the body thereby making it possible for every organ of the body to perform its functions optimally (McDonald et al., 1998; Okeke and Adaku, 2009). Moisture accounts for most of the biochemical and physiological reactions in living cells (Guisseppe and Baratta, 2000). 
Crude fibre, protein and ash contents were higher in the G. kola seeds used in the control experiment compared to the values of each of the parameters for the seeds stored in all the tested storage materials. Crude fibre slows down the rate of glucose absorption into the bloodstream, thereby reducing the risk of hyperglycemia (Bouttwell, 1998; Okeke and Adaku, 2009). Protein is essential for the survival of human beings and animals (Voet et al., 2012). Dietary ash has proved helpful in establishing and maintaining acidalkaline balance of the body system (Barborka, 1970; Hawkkins, 1979). Crude fat was found to be high in seeds stored in fresh plantain leaf at $3.81 \pm 0.01$. Fats are necessary for hormone production, insulation and protection of vital organs (Dutta, 1981).

CRIN (1971) studied the use of polythene bags, leaves of Cordofolia cola, and dry and fresh plantain leaves for storing kola nuts. These materials were found to affect the quality of kola nuts in terms of colour, crispness, and marketable quality. Similar studies carried out by Korie (1996) on the effect of packaging materials on Cola nitida, confirmed the effectiveness of polyethylene bags over other storage materials, as it is observed in this study. Ofor et al. (2010) projected the benefits in the use of polythene bags for storing G. kola, amongst other storage materials in Imo State, Nigeria.

Conclusion: In this study, polythene bag was found to improve the longevity of $G$. kola seeds over all other storage materials but there was reduction of carbohydrate and protein contents of the seeds when stored in this material.

\section{REFERENCES}

Adebisi, A. A. (2004). A case study of Garcinia kola nut production to consumption system in J4 Area of Omo Forest Reserve, South - west Nigeria.. Africa (2): 115 132.

Adesuyi, A. O. Elumm, I. K., Adaramola, F. B. and Nwokocha, A. G. M (2012). Nutritional and phytochemical screening of Garcinia kola. Adv. J. Food Sci. Technol. 4(1): 9-14

Aiyelaagbe, I.O., LabodePopoola, Adeola, A.O., Obisesan, K.O and Ladipo, D.O. (1996). Garcina kola: its prevalence, farmer valuation, and strategies for its conservation in the rainforest of southeastern Nigeria. Paper contributed to the workshop on the Rainforest of Southeastern Nigeria and Southwestern Cameroon held on 21-23 October, 1996 at Cross River National Park, Obudu Ranch, Nigeria.

Association of Analytical Chemists (A. O. A. C.) (2000). Official Methods of Analysis (17 $7^{\text {th }}$ Edition). Volume 1. Association of Official Analytical Chemists., Maryland, U.S.A.

Barborka, C.J. (1970). Treatment by Diets, ( $2^{\text {nd }}$ edition.). J.B. Lippincott Co, Philadelphia. 105pp.
Bouttwell, R. K. (1998). An Overview of the Role of Nutrition in Carcinogenesis, Nutrition, Growth and Cancer. Allan R. Liss Inc., London. 418pp.

Cocoa Research Institute of Nigeria (CRIN) (1971). Progress in Tree Crop Research in Nigeria. A Commemorative Book.

Dutta, A. C. (1981). Botany for Degree Students, $6^{\text {th }}$. Edition. Oxford University Press, New Delhi. 708pp.

Guisseppe, R. and Baratta, T. M. (2000). Antioxidant activity of selected essential oil components in two lipid model systems. Afri J. Biotechnol., 69(2): 167 - 174.

Hawkins, H. E. (1979). Applied Nutrition, $2^{\text {nd }}$. Edition. Lee Foundation for Research, Milwukee, Wisconsin. 217pp.

Korie, C. N. (1996). Effect of different packaging materials on the shelf-life of Kola (Cola nitida). B. Agic. Tech. (Crop production) Project Report, Federal University of Technology, Owerri, 62pp

Ladipo D.O. (1995). Management and genetic improvement of MPTS in humid lowlands of West and Central Africa. p 79. In: ICRAF 1995 annual report. ICRAF, Nairobi, Kenya.

McDonald, K. A. ; Penno, J. W. ; Kolver, E. S. ; Carter, W. A. ; Lancaster, J. A., (1998). Balancing pasture and maize silage diets for dairy cows using urea, soybean meal or fishmeal. Proceedings of the New Zealand Society of Animal Production, 58: 102-105

Ntamag, C.N. (1997). Spatial distribution of non-timber forest product collection. A case study of South Cameroon. Unpublished M.Sc. dissertation, Wageningen Agricultural University, the Netherlands

Nwoboshi, L. C. (1982). Tropical Silviculture: Principles and Techniques. Ibadan University Press. 333pp.

Oboho, E. G. and Ngalum, E. L. (2014). Germination response of Treculia Africana (Dacne) seeds in relation to moisture content, storage method and its duration. $J$. of Appl. Nat. Sci. 6(1):88 -94.

Ofor, M. O., Ngobili, C. A. and Nwufo, M. I. (2004). Ethnobotanical uses and trade characteristics of Garcinia kola in Imo State, Nigeria. Int. J. Agric Rural Dev., 5: 140144

Okeke C. U., Adaku, C. N. (2009). Phytochemical and Proximate Analyses of Euphorbia heterophyllaLinn. (Euphorbiaceae). Nig. J. Bot. 22(1): 215-222.

Onochie CFA, Stanfield DF (1960). Nigerian Trees. Gov. Printer, Lagos, Nigeria. pp. 5-10.

Voet, D., Pratt, C. W. and Voet, J. G. (2012). Principle of Biochemistry, $4^{\text {th }}$ Edition International Student Version. John Wiley and Son, Hoboken. 